SCJR 12, no. 1 (2017): 1-13

\title{
Origen in the Likeness of Philo: Eusebius of Caesarea's Portrait of the Model Scholar
}

\author{
JUSTIN M. ROGERS \\ jrogers@fhu.edu \\ Freed-Hardeman University, Henderson, TN 38340
}

The name of Philo of Alexandria occurs more in the writings of Eusebius of Caesarea than in those of any other ancient author. Philo's name can be located over 20 times in the surviving literary corpus of Eusebius, ${ }^{1}$ and there is strong evidence that Eusebius' Caesarean library is the very reason Philo's works exist today. $^{2}$ In all probability, the core of this library can be traced to the personal collection of Origen when he settled in Caesarea in 232 CE. ${ }^{3}$ Eusebius' own teacher Pamphilus expanded the library, and took great pains to copy and preserve Origen's own works. What we have, then, is a literary union between Philo and Origen, Alexandrians within the same exegetical tradition. But we can go further.

Ilaria Ramelli has argued that Eusebius' accounts of Philo and Origen in the Ecclesiastical History are strikingly similar, picking up Robert Grant's stress on the similarity between Origen and the Philonic Therapeutae. ${ }^{4}$ Here, I further Ramelli's work by noting additional similarities in the Eusebian biographical presentations. I also point to the tension Eusebius felt between Philo Christianus and Philo Judaeus, a tension detectible in his presentation of the Therapeutae, a group about whom Philo reported and whom Eusebius considered to be the first Egyptian Christians. ${ }^{5}$ The result is that Eusebius recognized Philo to be exegetically closer to Christianity, and religiously closer to Judaism. This realization

\footnotetext{
${ }^{1}$ For the references to Philo in Eusebius see the list in David T. Runia, "Philo in the Patristic Tradition," in Reading Philo: A Handbook to Philo of Alexandria, ed. Torrey Seland (Grand Rapids: Eerdmans, 2014), 268-86, 278-79.

${ }^{2}$ See David T. Runia, "Caesarea Maritima and the Survival of Hellenistic-Jewish Literature," in Caesarea Maritima: A Retrospective After Two Millennia, ed. A. Raban and K.G. Holum (Leiden: Brill, 1996), 476-95. The conclusions of Runia are accepted in the most recent treatment of the subject: Andrew Carriker, The Library of Eusebius of Caesarea (Leiden: Brill, 2003).

${ }^{3}$ I follow the chronology of Pierre Nautin, Origène: Sa vie et son oeuvre (Paris: Beauchesne, 1977).

${ }^{4}$ Ilaria L.E. Ramelli, "The Birth of the Rome-Alexandria Connection: The Early Sources on Mark and Philo, and the Petrine Tradition," Studia Philonica Annual 23 (2011): 69-95. Robert M. Grant, Eusebius as Church Historian (Oxford: Clarendon, 1980), 73-74.

${ }^{5}$ Philo's "conversion" to Christianity is a later development, but the seeds are already in Eusebius. For a survey of the Christian reception of Philo see David T. Runia, Philo in Early Christian Literature: A Survey (Assen/Minneapolis: Van Gorcum/Fortress, 1993). On the Byzantine period specifically, see now Runia, "Philo in Byzantium: An Exploration," Vigiliae Christianae 70 (2016): 259-281.
} 
created an ambiguity in the Ecclesiastical History in which Eusebius explicitly presented Philo not as a Jew, but as a "Hebrew."

\section{Eusebius' Portraits of Philo}

About Philo's life, we learn very little from Eusebius that we could not extract from a combination of Philo's own scattered comments and from the brief notice in Josephus. ${ }^{6}$ The one noteworthy piece of information, which Eusebius introduced with $\lambda$ ó ${ }_{0} \varsigma$ है $\chi_{\chi \varepsilon l}$ ("as the story goes"), ${ }^{7}$ is that Philo "encountered Peter" in Rome. ${ }^{8}$ Eusebius obviously anticipated objections to the report because he went on to say, "And this would not be unlikely," and cited as evidence Philo's account of the Therapeutae, whom Eusebius considered to be Christians. ${ }^{9}$ So Eusebius wished his readers to think that Philo's meeting with Peter was authentic because Philo praised the first Christians in Egypt; here too Eusebius felt obligated to defend his identification. ${ }^{10}$

\section{Philo in Eusebius' Ecclesiastical History 2.4.2-3}

We turn now to discuss Eusebius' presentation of Philo as a renowned scholar of his day, who knew and recognized the significance of the first Christians of Egypt. Eusebius began by stressing Philo's reputation for learning:

In his reign [Gaius Caligula's] Philo became generally known as a man of the greatest distinction, not only among our own people but also among those of heathen education. He was a Hebrew by racial descent but inferior to none of the magnates in authority in Alexandria. The extent and quality of the labour he bestowed on the theological learning of his race is in fact patent to all, and it is not necessary to say anything of his position in philosophy and the liber-

\footnotetext{
${ }^{6}$ The only information Josephus offers is found in Ant. 18.259: "Philo, the leader of the Jewish embassy [to Gaius Caligula], a man esteemed in all things, brother of Alexander the Alabarch, and not

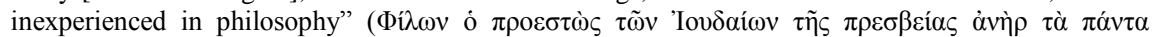

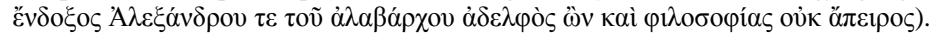

${ }^{7}$ This citation formula has been analyzed by Carriker, The Library, 63-68, who observes that the phrase normally, although not always, introduces a written source in Eusebius. B. Gustafsson, "Eusebius' Principles in Handling His Sources, as Found in his Church History, Books I-VII," Studia Patristica 24 (1961): 436, states that Eusebius generally uses oral sources only for material closer to his own time (i.e., from book 6 onward). As David Runia, Philo in Early Christian Literature, 7, seems to suggest, Eusebius' source here may have been Clement of Alexandria, since he is quoted immediately before this point in the narrative.

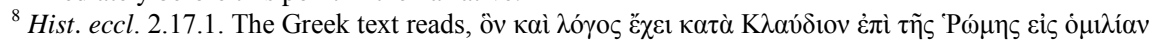

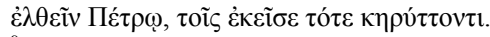

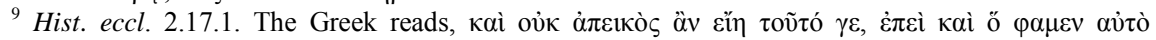

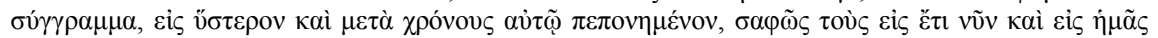

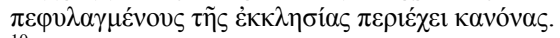

${ }^{10}$ The account is a piece of carefully constructed rhetoric aiming at persuasion, and clearly anticipating objection. See Sabrina Inowlocki, "Eusebius of Caesarea's 'Interpretatio Christiana' of Philo's De vita contemplativa," Harvard Theological Review 97 (2004): 305-328.
} 
al studies of the heathen world since he is related to have surpassed all his contemporaries, especially in his zeal for the study of Plato and Pythagoras. ${ }^{11}$

Our concern here is not to determine whether Eusebius was historically correct about the Therapeutae, ${ }^{12}$ but to examine how he presented Philo as a scholar. ${ }^{13}$ Indeed, a little later Eusebius says of Philo, "Moreover, from his very accurate description of the life of our ascetics it will be plain that he not only knew but welcomed, reverenced, and recognized the divine mission of the apostolic men of his day, who were, it appears, of Hebrew origin, and thus still preserved most of the ancient customs in a strictly Jewish manner."14 Later Eusebius says, "Philo was rich in language and broad in thought, sublime and elevated in his views of the divine writings, and had made various and diverse his exposition of the sacred words." 15

Eusebius carefully crafted his vocabulary to make Philo neither a Christian nor an opponent, but respected by both. ${ }^{16} \mathrm{He}$ was "a man most noted"

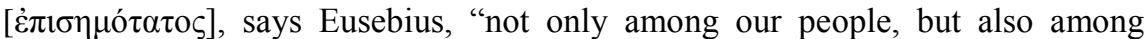
those eager for education outside." 17 Having introduced his reputation both among Christians and pagans, Eusebius then referred to Philo's Hebraic descent. It is true that Philo here and elsewhere, along with Josephus, received the more honorary Eusebian designation of "Hebrew" as opposed to the more hostile "Jew." But the term "Hebrew" was not always clearly positive, and the term

${ }^{11}$ Hist. eccl. 2.4.2-3, trans. Kirsopp Lake, Loeb Classical Library (Cambridge, MA: Harvard Univer-

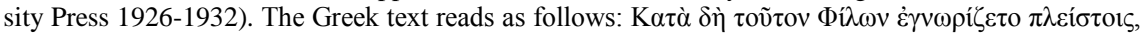

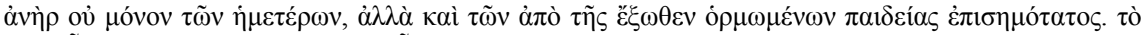

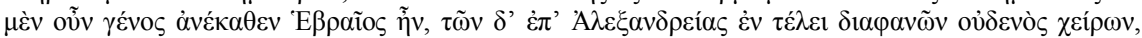

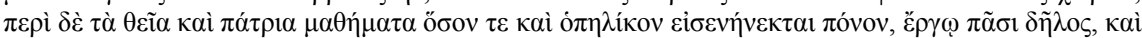

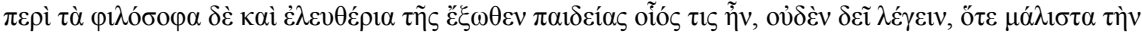

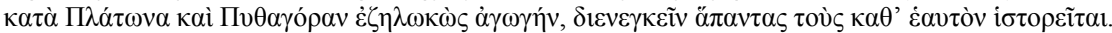

${ }^{12}$ According to the Acts of the Apostles 2:10, certain "Alexandrians" were in attendance at Pentecost, although we cannot know that these Alexandrian Jews were converted, as Robert Grant assumes in his Eusebius as Church Historian, 51.

${ }^{13}$ On Eusebius' presentation of people see Grant, Eusebius as Church Historian, 76-83.

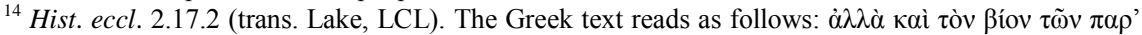

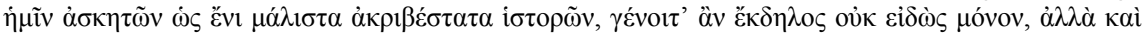

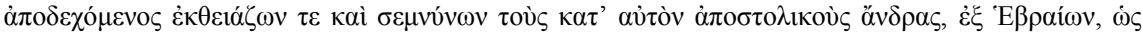

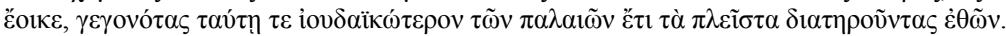

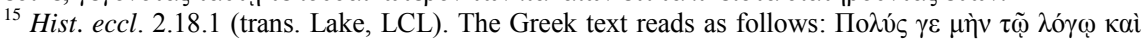

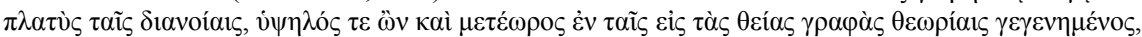

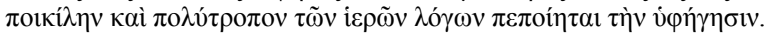

${ }^{16}$ Eusebius' portrait serves to identify Philo as both "other" and familiar (for a similar strategy of treating heresy, see Eduard Iricinschi and Holger M. Zellentin, Heresy and Identity in Late Antiquity 1-21). A similar attempt to sketch oneself through the eyes of the familiar other is observable in the Christian ethnographic tradition as well. See Todd S. Berzon, Classifying Christians: Ethnography, Heresiology, and the Limits of Knowledge in Late Antiquity (Berkeley: University of California Press, 2016), esp. chs. 2-4.

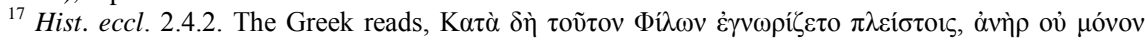

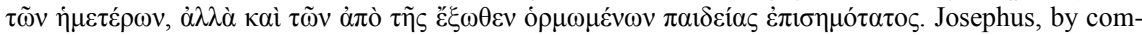

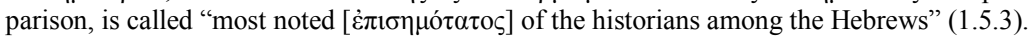


"Jew" was associated with Philo and Josephus elsewhere in Eusebius. ${ }^{18}$ In fact, Sabrina Inowlocki's research leads her to the conclusion that, at least in his apologetic writings, Eusebius applied the term "Hebrew" to Jewish authors only when he "intend[ed] to connect them to Christianity." 19 This general observation holds true for the Philo materials in the Ecclesiastical History as well.

Connecting "Hebrews" with Christianity was indeed an overt aim of Eusebius. After responding to the sensitive point that the term "Christian" was new to human vocabulary, Eusebius wrote:

But even if we are clearly new, and this really fresh name of Christians is recently known among all nations, nevertheless our life and method of conduct [ $\tau \tilde{\eta} \varsigma \dot{\alpha} \gamma \omega \gamma \tilde{\eta} \varsigma \dot{o} \tau \rho o ́ \pi 0 \varsigma]$, in accordance with the precepts of religion, has not been recently invented by us, but from the first creation of man, so to speak, has been upheld by the natural concepts of the men of old who were friends of God, as we will here demonstrate. The race of the Hebrews is not new but is honoured among all men for its antiquity and is itself well known to all. ${ }^{20}$

Eusebius then goes on to state emphatically that all the righteous characters from Adam to Abraham might well be called "Christians in fact, if not in name." the original "Christians" were actually "Hebrews.",22

It aligned with Eusebius' introductory agenda, then, to locate the first Egyptian Christians among the Hebrew community of Alexandria. A Hebrew might be a "Jew," of course, but could also be a Christian, depending on the chronology of the individual in question. Eusebius called the Hellenistic Jewish author Aristobulus and Eleazar, the High Priest in the Letter of Aristeas, "Hebrews by race but [who] flourished chronologically at the time of the Ptolemies." 23 Philo was likewise a "Hebrew" by race, although the chronology of Philo's life must have created a problem in the mind of Eusebius. He was a contemporary of the Apostles, and even met Peter. This ought to suggest his Christian conversion.

\footnotetext{
${ }^{18}$ On these terms in Eusebius as they relate to Philo and Josephus see Sabrina Inowlocki, Eusebius and the Jewish Authors: His Citation Technique in an Apologetic Context (Leiden: Brill, 2006), 10538.

${ }^{19}$ Inowlocki, Eusebius and the Jewish Authors, 121.

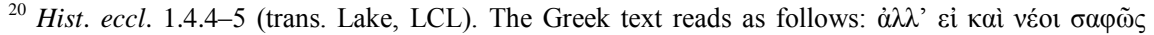

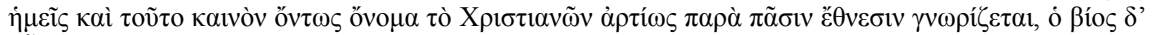

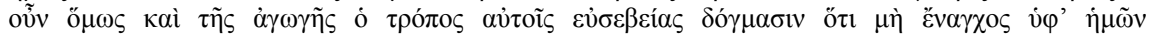

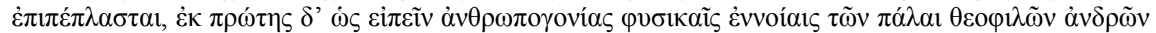

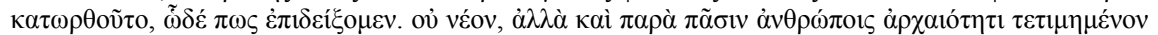
ع $\theta v o \varsigma, \tau$,

${ }^{21}$ Hist. eccl. 1.4.6. On this question see Aryeh Kofsky, Eusebius of Caesarea Against Paganism (Leiden: Brill, 2000), 100-36.

${ }^{22}$ Using the name "Hebrew" would have distanced the Christians from contemporary Jews with whom they were still in debate, which served an apologetic interest when engaging pagan intellectual culture. On Porphyry's respect for the theology and religious devotion of the Jews, see Aaron P. Johnson, Religion and Identity in Porphyry of Tyre: The Limits of Hellenism in Late Antiquity (Cambridge: Cambridge University Press, 2013), 273-82.

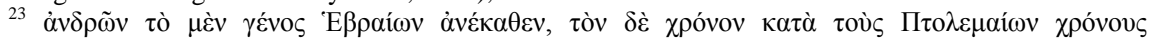

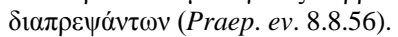


However, Philo's own writings, well-known to Eusebius' readers, gave no hint that he accepted Christian faith. Thus he was dropped at the doorstep of Christian conversion. $^{24}$

The term "Hebrew" alone is not enough for Eusebius' readers to know for sure the religious identity of someone living at the beginning of the Christian era. But Eusebius complicated matters further. After acknowledging the Therapeutae were indeed "from the Hebrews" [ $\dot{\varepsilon} \xi$ "E $\beta \rho \alpha i \omega v]$, he stated they "were still rather

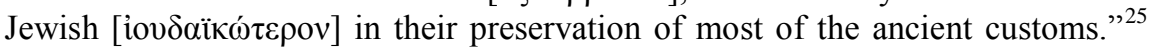
According to Inowlocki, the comparative adjective "rather Jewish" in the Ecclesiastical History elsewhere describes "Christian groups willing to keep Jewish law, such as the Ebionites, ${ }^{26}$ or those willing to interpret the scriptures as the Jews do, like the schismatic Nepos." ${ }^{27}$ Eusebius, then, identified the Therapeutae, as Jewish Christians, while allowing his source of information about them, Philo, to remain only a Hebrew. ${ }^{28}$ This left Philo's own status ambiguous.

Eusebius' identifying both Philo and the Therapeutae as "Hebrews" drew on his discussion in Ecclesiastical History 1.4.4-5 about Hebrews being the original "Christians," 29 and thus served to create a comparative ambiguity between the identities of Philo and the Therapeutae. ${ }^{30}$ Eusebius hinted at Philo's connection with the "original" Hebrews with the adverb $\alpha v \varepsilon$ ć $\alpha \theta \varepsilon v$ ("originally, formerly," or "by birth"). This term may not mean that Philo was a Hebrew "by birth," for this much is implied by the term $\tau$ ò $\gamma \varepsilon$ ćvo ("race"). It could either be that Philo is connected with the "original" Hebrews by race (i.e., those pre-Christian "Christians"), ${ }^{31}$ or that he was "formerly" a Hebrew by race. ${ }^{32}$ This interpretation squares with what Inowlocki says the term "Hebrew" means in Eusebius. It is chronological insofar as it refers to virtuous people prior to the Mosaic Law, and it is religious/ethical insofar as it refers to righteous Jews after the Law independent of their keeping it. ${ }^{33}$ So again, we are confronted with an ambiguity.

\footnotetext{
${ }^{24}$ J.E. Bruns, "Philo Christianus: the Debris of a Legend," Harvard Theological Review 66 (1973): 142, assumes that Eusebius accepted Philo's conversion to Christianity. I do not think Eusebius provides enough information for us to draw that conclusion definitively.

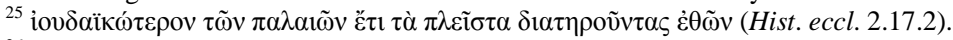

${ }^{26}$ Hist. eccl. 6.17.1.

${ }^{27}$ Hist. eccl. 7.24.1; "Eusebius of Caesarea's 'Interpretatio Christiana,"” 312.

${ }^{28}$ By way of comparison it should be noted that the entire Jerusalem church before the time of Hadrian "consisted of Hebrews" (Hist. eccl. 4.5.2). Eusebius thus may have an apologetic motive in linking the "original" Jerusalem church with the Alexandrian Therapeutae to lend credibility to the latter's Christian identity.

${ }^{29}$ Eusebius is clear that the Therapeutae are Christians even if the name is never assigned to them (Hist. eccl. 2.17.4-6).

${ }^{30}$ Timothy Barnes, Constantine and Eusebius (Cambridge: Harvard University Press, 1981), 185, observes, "Judaism comes into Eusebius' scheme as a purely transitional stage, to prepare the way for the new covenant of Jesus which diffused the religion of the patriarchs to all mankind."

${ }^{31}$ This seems to be the meaning intended in Hist. eccl. 1.22.2.

${ }^{32}$ The term does refer to ethnic Jews who were converted, for all the bishops of Jerusalem, Eusebius says, were Hebrews àvéк $\alpha \theta \varepsilon v$ (Hist. eccl. 4.5.2).

${ }^{33}$ Inowlocki, Eusebius and the Jewish Authors, 112.
} 
Ironically, Eusebius' Philo was more Christian than the actual "Christian" Therapeutae whose activity he reports, for Philo was never described as being

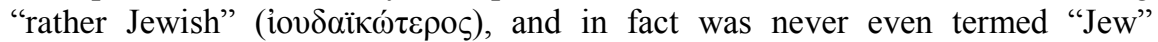
(Iovdaios) in the Ecclesiastical History. Surely this is intentional. But neither did Eusebius explicitly convert him. Philo was almost a Christian just as the Therapeutae were almost Jews.

\section{Philo in Ecclesiastical History 2.17}

The second section of biographical information on Philo comes immediately before Eusebius discusses the Therapeutae. A careful analysis of Eusebius' language here reveals just how much he presented Philo as admiring Christianity. ${ }^{34}$ It is indeed difficult to imagine someone so smitten with Christianity (as Eusebius presents the evidence) who did not himself convert. Immediately before citing Philo's account of the Therapeutae, Eusebius wrote that Philo "not only knew

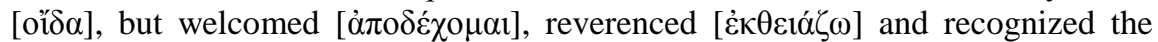

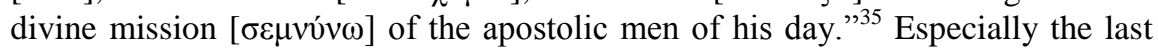
two terms, $\dot{\varepsilon} \kappa \theta \varepsilon i \alpha ́ \zeta \omega$ and $\sigma \varepsilon \mu v v ́ v \omega$, carry specialized senses deserving analysis.

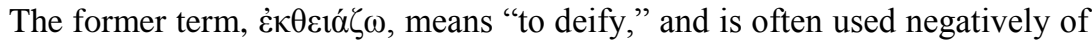
idols, ideas and creatures worshipped among the pagans. ${ }^{36}$ The term can be used, however, of reverence or admiration, especially of non-Christians toward the Christian life. For instance, Clement, after citing a number of texts to demonstrate that "Christian" virtue is valued among the Greeks, concluded, "You see how

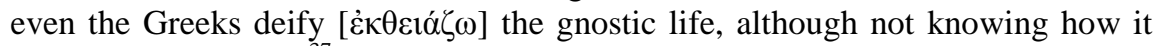
must be understood." ${ }^{37}$ The author of the Exhortation to the Greeks, in giving his account of the translation of the Septuagint, portrayed Ptolemy II Philadelphius marveling at the work, and calling the translators "godloving men" $(\theta \varepsilon \circ \varphi \uparrow \lambda \varepsilon i \bar{\varsigma}$

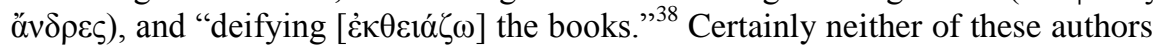
wished to express deification literally, as did the Neo-Platonists, for whom the

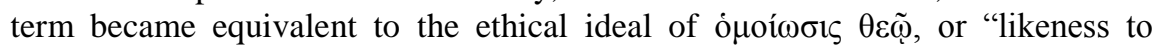

\footnotetext{
${ }^{34}$ Inowlocki's discussion of Eusebius' language, "Eusebius of Caesarea's 'Interpretatio Christiana,", 320-21, is confused and unnecessarily critical of Lake's translation. To begin, she discusses what she perceives to be the mistranslation of three participles when in fact there are four in question (which

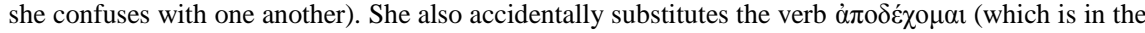

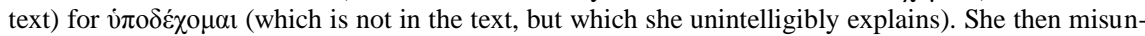

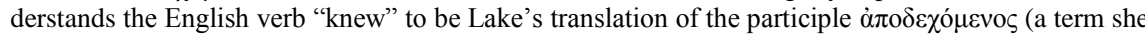

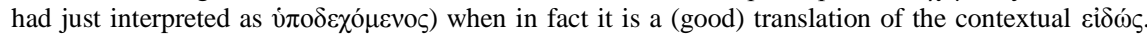
Finally, she understands Lake's translation of $\sigma \varepsilon \mu v$ v́v to be only "to recognize" when in fact it is "to recognize the divine mission," a startling close equivalent to Inowlocki's proposed rendering, "to recognize as divine."

${ }^{35}$ Hist. eccl. 2.17 .2 (trans. Lake, LCL).

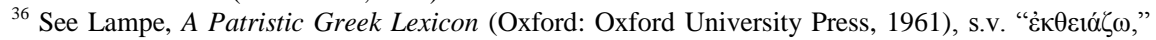
427, and the word study in Norman Russell, The Doctrine of Deification in the Greek Patristic Tradition (Oxford: Oxford University Press, 2005), 341-42, although the latter does not mention Eusebius' usage.

${ }^{37}$ Strom. 5.11.69.

${ }^{38}$ Cohort. 14.B.
} 
God."39 But for Eusebius and his colleagues the strong metaphor elevated those occasional non-Christians who recognized distinctively "Christian" (anachronistically applied) truths. This word thus speaks in favor of Philo's remaining an outside admirer of Christianity.

The second term, $\sigma \varepsilon \mu v v ́ v \omega$, again reminds us of divination, for the term often means "to honor as divine." 40 In Eusebius, though, the term most often indicates "irreverent boasting." This context is one of the few occasions in which the term is positive in Eusebius. Kirsopp Lake translates the term in such a way as to stress that Philo "recognized the divine mission" of the first Egyptian Christians. Like Josephus, who recognized the greatness of John the Baptizer and Jesus, ${ }^{41}$ Philo

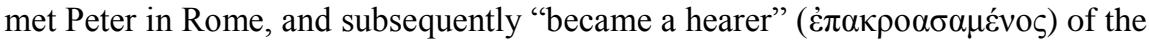
Therapeutae, a participle that might hint at the philosophical technical term $\dot{\alpha} \kappa \rho о \alpha \tau \eta \dot{\zeta} .{ }^{42}$ Thus, this description of Philo suggests that Eusebius was asking, "How could Philo have described Christianity in such glowing terms, and possibly have been a student of Peter himself, and yet not have been converted?" Such a combination of honorable terms is rare in Eusebius' biographical presentations, and indeed sets Philo apart. It would not be inconceivable for a reader of Eusebius to jump to the conclusion that Philo described the Therapeutae when he was still an outsider to Christianity, but later in his life, after "hearing" the Apostle Peter, converted to become a Christian himself.

\section{Eusebius' Portraits of Philo and Origen Compared}

In contrast to his brief discussions of Philo, Eusebius spent a significant portion of Book Six of his Ecclesiastical History detailing the life of Origen, from his childhood to his martyrdom. Eusebius in fact gave far more attention to Origen than to any other figure. In his portrait, Eusebius described Origen's prodigious learning, his religious fervor, his philosophical life, his ecclesiastical conflicts and finally his worldwide renown from Caesarea. Lorenzo Perrone suggests Eusebius' purpose, writing, "This biographical sketch, even if we take into account its apologetic tendency, offers a very clear idea of the principles and values that should inspire the conduct of a Christian writer." 43 Beyond this, though, Patricia Cox Miller, in her thorough analysis of the account, isolates two major apologetic purposes. ${ }^{44}$ Eusebius wished first to defend Origen against those who questioned his Christian orthodoxy, and second, to defend him against those who

\footnotetext{
${ }^{39}$ See Plato's Theaet. 176B, and its interpretation in Porphyry (Marc. 17) and Proclus (e.g., El. Theol. $129,135,153)$.

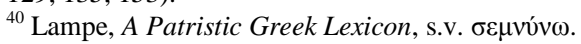

${ }^{41}$ Josephus, Ant. 18.63 (Jesus); 18.116-117 (John). On Eusebius' discussions see Hist. eccl. 1.11.3-9.

${ }^{42}$ Hist. eccl. 2.17.12: "This seems to have been said by a man who had listened to their expositions of

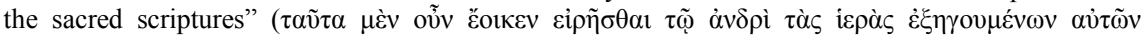

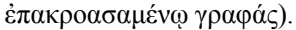

43 "Eusebius of Caesarea as a Christian Writer" in Caesarea Maritima ...,516.

${ }^{44}$ Biography in Late Antiquity: A Quest for the Holy Man (Berkeley: University of California Press, 1983), 69-101.
} 
questioned his philosophical integrity. ${ }^{45}$ These purposes were exemplified in a most extreme way. Eusebius could cite Porphyry as a witness to Origen's pagan philosophical acumen, and could also himself boast of Origen's ascetic act of self-castration! Porphyry's testimony represents a ringing endorsement from one of the finest philosophical minds of Late Antiquity, and Origen's ascetic deed suggests the strictest spiritual discipline.

Eusebius' presentation of Philo's biography was missing this overt apologetic, but he portrayed Philo in terms similar to Origen, both as a renowned philosophical mind and as a noted scriptural exegete. The following chart expands slightly on Ramelli's categories of the correspondences between Philo and Origen in Eusebius' Ecclesiastical History: ${ }^{46}$

\begin{tabular}{|c|c|c|}
\hline Category & Philo & Origen \\
\hline Famous for learning & 2.4 .2 & $\begin{array}{l}6.2 .15 ; 6.18 .2 ; 6.19 .5 \\
\text { (a quotation of } \\
\text { Porphyry); } 6.21 .3\end{array}$ \\
\hline $\begin{array}{l}\text { A reputation even among } \\
\text { pagans }\end{array}$ & 2.4 .2 & $6.3 .1,13 ; 6.30 .1$ \\
\hline $\begin{array}{l}\text { Noted for scriptural } \\
\text { learning }\end{array}$ & $2.4 .2 ; 2.18 .1$ & $\begin{array}{l}6.2 .7-9 ; 6.3 .9 \\
16.1 .1 ; 6.21 .3\end{array}$ \\
\hline $\begin{array}{l}\text { Extraordinary labor } \\
\text { ( } \pi \text { óvos) }\end{array}$ & 2.4 .2 & $6.2 .7,9 ; 6.3 .7,13$ \\
\hline Large literary oeuvre & $2.4 .2 ; 2.18 .1-8$ & $\begin{array}{l}6.23 .1-6.25 .13 \\
6.32 .1-3\end{array}$ \\
\hline $\begin{array}{l}\text { Philosophical competence } \\
\text { and recognition }\end{array}$ & 2.4 .2 & $6.18 .2-6.19 .14$ \\
\hline $\begin{array}{l}\text { Acquaintance with Plato- } \\
\text { nism and Pythagoreanism }\end{array}$ & 2.4 .2 & $6.19 .7-8$ \\
\hline
\end{tabular}

\footnotetext{
${ }^{45}$ Cox Miller, Biography, 70.

${ }^{46}$ I borrow the similarities from Ramelli, "The Birth," 79-80, but trace most of the explicit references myself.
} 
Some might think these similarities are sufficiently broad to be applied to virtually any thinker Eusebius admired. But this is not the case. For example, Elizabeth Penland asserts that Eusebius' portrait of his teacher Pamphilus was patterned after Origen's biography in the Ecclesiastical History, ${ }^{47}$ yet his comments on the life of Pamphilus conformed only to two of the above-mentioned categories, namely his extraordinary labor and his renown for scriptural learning. ${ }^{48}$ Eusebius emphasized these same two qualities in his accounts of Clement of Alexandria as well, ${ }^{49}$ although it is remarkable that he credited Clement, who cited Plato by name over 150 times in his own works, only with general knowledge of "the opinions of the philosophers." 50 In fact, although Eusebius named Plato over 450 times in his Preparation for the Gospel, he mentioned him only three times in the Ecclesiastical History, once in connection with Philo, once in connection with Origen, and once in a direct quotation from Justin Martyr. ${ }^{51}$ Other church leaders partially match Philo's biography, but none as closely or specifically as Origen. ${ }^{52}$

It seems, then, that Eusebius can be regarded as having followed a characteristic outline when presenting his heroes in the Ecclesiastical History, for many of them share common elements. But no author received as full a treatment as Origen, and Origen's biography is closer to Philo's than to any other figure about whom Eusebius reported. Eusebius, it seems, expanded his model in his portraits of Philo and Origen, intentionally presenting the two as equals. This leads us to the conclusion that Eusebius regarded Philo as a representative scholar just like Clement, Origen, and even his personal teacher, Pamphilus. ${ }^{53}$ The difference, of course, is that he identified these other figures explicitly as Christians. Philo was not. His meeting with Peter ought to suggest that Philo converted, but neither Eusebius nor Jerome made this claim explicitly. ${ }^{54}$ Through their biographical similarities, Philo and Origen stood as pillars of learning and scriptural exegesis. Philo may have represented the finest "Christian" scholarship, but he was not himself clearly Christian.

\footnotetext{
${ }^{47}$ It should be noted that Eusebius emphasized the "philosophic life," and thus formed a connection between Origen and Pamphilus that was not present in his account of Philo (see Penland, "The History of the Caesarean Present: Eusebius and Narratives of Origen," in Eusebius of Caesarea: Tradition and Innovations, ed. Aaron Johnson and Jeremy Schott (Washington, D.C.: Center for Hellenic Studies, 2013), http://chs.harvard.edu/CHS/article/display/5870.

${ }^{48}$ His "industry" ( $\sigma \pi \circ \nu \delta \eta \dot{)}$ is in reference to his assembling the works of Origen (see Hist. eccl. 6.32.3). His fame is further emphasized in Mart. Pal. 11.2.

${ }^{49}$ Hist. eccl. 5.11.1-5; 6.6; 6.13.1-9.

${ }^{50}$ Hist. eccl. 6.13.5.

${ }^{51}$ Hist. eccl. 2.4.3 (Philo), 4.8 .5 (Justin) and 6.19.8 (Origen).

${ }^{52}$ Both Josephus (Hist. eccl. 3.9) and Justin (Hist. eccl. 4.11.8-11; 4.18.1-3) match in particulars, but not in all of the categories here outlined.

53 Jerome followed Eusebius in portraying Philo as the model scholar (see Vir. ill. 8, 11, which is mostly a paraphrase of Eusebius' Ecclesiastical History), but resisted drawing explicit comparison between Philo and Origen. For Jerome's Latin readers, Varro was placed in this honored position (Epist. 33.4, referenced in Vir. ill. 54.8). Did Jerome read Eusebius the way I suggest we should we read him, but substituted Varro (a non-Christian Latin literary giant) for Philo (a non-Christian Greek literary giant)? I am grateful to an anonymous reviewer for suggesting this intriguing possibility.

${ }^{54}$ Photius reports that Philo did convert, but later apostatized (Bib. cod. 105).
} 


\section{Eusebius' Motives}

Assuming we are correct about our proposals above, why did Eusebius wish to establish such a close connection between Philo and Origen? There are at least two answers to this question. First, we must believe Eusebius was simply following the lead of Origen himself. Even though Origen only mentioned Philo by name three times in his extant works, ${ }^{55}$ he referred to him anonymously as a "predecessor" no less than twenty three additional times. ${ }^{56}$ Ilaria Ramelli expresses the importance of these references as follows:

Origen tends expressly to refer to Philo as a predecessor precisely in points that are crucial to his Scriptural allegorical method. This strongly suggests that Philo was his main inspirer for the very technique of philosophical allegoresis of Scripture, and that Origen both was well aware of this and acknowledged his debt. ${ }^{57}$

Eusebius may have been one of the few early Christians in a position to read Philo's works thoroughly enough to recognize the actual source of Origen's anonymous references to predecessors.

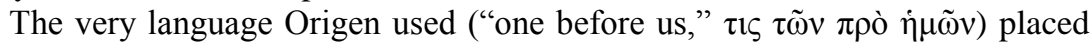
Philo squarely in the tradition of which Origen considered himself an heir. Add to this the use of Philo Eusebius most certainly observed in Clement of Alexandria. ${ }^{58}$ Eusebius, therefore, must have recognized the importance of Philo in the tradition of Alexandrian scriptural exegesis as it had come down to him, ${ }^{59}$ but wished not to identify Philo, the originator of this tradition, explicitly as a Jew. ${ }^{60}$ Philo still remained dangerously Jewish, not in terms of his scriptural interpreta-

\footnotetext{
${ }^{55}$ Cels. 4.51; 6.21; Comm. Matt. 15.3.

${ }^{56}$ Research into Philo's influence on Origen is summarized in my forthcoming, "Origen's Use of Philo Judaeus," in The Oxford Handbook of Origen (Oxford: Oxford University Press). The excellent survey and catalogue of Annewies van den Hoek is a starting point for all subsequent research. See her "Philo and Origen: A Descriptive Catalogue of their Relationship, Studia Philonica Annual 12 (2000): 44-121; and "Assessing Philo's Influence in Christian Alexandria: The Case of Origen," in Shem in the Tents of Japheth: Essays on the Encounter of Judaism and Hellenism (Leiden: Brill, 2002), 223-39.

57 "Philo as Origen's Declared Model: Allegorical and Historical Exegesis of Scripture," Studies in Christian-Jewish Relations 7 (2012): 6 (http://ejournals.bc.edu/ojs/index.php/scjr).

${ }^{58}$ On Clement's use of Philo see Annewies van den Hoek, Clement of Alexandria and His Use of Philo in the Stromateis: An Early Christian Reshaping of a Jewish Model (Leiden: Brill, 1988).

${ }^{59}$ On the Alexandrian "tradition" as it is transmitted in Clement, see van den Hoek, "How Alexandrian was Clement of Alexandria? Reflections on Clement and his Alexandrian Background," Heythrop Journal 31 (1990): 179-94.

${ }^{60}$ Such a move is found for the first time in Theodore of Mopsuestia's Treatise Against the Allegorists. See Frederick G. McLeod, Theodore of Mopsuestia (New York: Routledge, 2010), 75-79 in English. For the Syriac text with French translation see Lucas Von Rompay, Théodore de Mopsueste: Fragments syriaques du Commentaire des Psaumes (Psaume 118 et Psaumes 138-148) (Louvain: Peeters, 1982).
} 
tion (he was quite "Christian" here), but in terms of his religion. ${ }^{61}$ Yet Philo as Christian was not an explicit step Eusebius wished to take.

Perhaps anti-Judaic apologetics led Eusebius to "convert," as it were, the Therapeutae, who provided Eusebius with "evidence" of first generation Egyptian Christianity. ${ }^{62}$ Since Philo was his only source for the Therapeutae, Philo played the useful role of an outsider who recognized the merits of the earliest Christians. In this way, he received similar treatment to Josephus. However, the exegetical connections between Origen and Philo were too obvious to be dismissed. Philo was not just a historian providing facts; his exegesis was woven into the fabric of Origen's own work. Philo was then to be regarded as part of the Christian tradition without necessarily becoming a Christian himself. ${ }^{63}$

Secondly, one of Eusebius' greatest desires was to establish continuity between contemporary and original Christian communities. ${ }^{64}$ This goal was complicated in the case of Alexandria by two factors. First, Eusebius dated the presence of the church and the renowned catechetical school there to the most ancient times in Christian history. The only information Eusebius appears to have had about the Alexandrian church is that Mark first preached the Gospel in Egypt. ${ }^{65}$ Everything else he claims for Egyptian Christianity must come from Philo. Second, the only firm information we have about Alexandrian Christianity prior to the time of Pantaenus (flourit ca. $180 \mathrm{CE}$ ) would lead us to associate it with the Gnostic activities of Basilides (flourit ca. $125 \mathrm{CE}$ ) and the formative years of Valentinus (flourit ca. 135) ${ }^{66}$ Eusebius needed to ignore this "heterodox" period to establish his thesis of orthodox purity from the beginning (i.e., from Philo's time) to Origen. ${ }^{67}$ This served to confirm Origen's own orthodoxy.

So Philo served not only to offer Eusebius an eyewitness account of the first Alexandrian "Christians," but also, I would argue, to link the latter day catecheti-

${ }^{61}$ N.R.M. de Lange, Origen and the Jews: Studies in Jewish-Christian Relations in Third Century Palestine (Cambridge: Cambridge University Press, 1976), 105, says of Origen that he "never speaks of the Jewish interpretation as literal except to condemn it." As we have discussed, Eusebius would follow such a distinction between hostile Jew and honorable Hebrew.

${ }^{62}$ The Jews are Eusebius' most often-mentioned opponents (see Barnes, Constantine and Eusebius, 164-88).

${ }^{63}$ Barnes calls Philo for Eusebius "a quasi-Christian" (Constantine and Eusebius, 130).

${ }^{64}$ This is one of the five primary themes of the Ecclesiastical History proposed by Grant, Eusebius, 45-59.

${ }^{65}$ Hist. eccl. 2.16.1. It appears that this information comes via Papias or Clement of Alexandria, or possibly both (see Hist. eccl. 2.15.2).

${ }^{66}$ Attila Jakab, Ecclesia Alexandrina: Evolution sociale et institutionnelle di christianisme alexandrine (II et III siecles) (Wien: Lang, 2001), 50, refers to Basilides as "le premier personage «chrétien» réellement connu à Alexandrie." On the difficultly of reconstructing this period, see C. Wilfred Griggs, Early Egyptian Christianity: From its Origins to 451 C.E. (Leiden: Brill, 2000), 4556, and Jakab, 49-89.

${ }^{67}$ The heretical beginnings of Alexandrian Christianity is a major cornerstone of Walter Bauer's famous thesis that heterodoxy preceded orthodoxy. See his Orthodoxy and Heresy in Earliest Christianity, ed. Robert Kraft and Gerhard Krodel (Philadelphia: Fortress, 1971); see also the reception history of the Bauer thesis in Thomas A. Robinson, The Bauer Thesis Examined: The Geography of Heresy in the Early Christian Church (Lewiston/Queenston: Mellen, 1988). 
cal school with the ancient one. ${ }^{68}$ Although Eusebius did not trace the history of the school directly to Philo, he did say "from ancient custom a school of sacred learning existed among them." ${ }^{, 69}$ Since Eusebius labored to identify a succession of individuals at the head of the catechetical school, at least from the time of Pantaenus, and a specific succession of bishops at the head of the church, we are inclined to assume that his "from ancient custom" is not a generic reference to the Therapeutae, but alluded instead to a certain anonymous individual, which alert and educated readers could readily assume to be Philo himself. Indeed, Mark was the only other individual he mentioned in connection with early Alexandrian Christianity, and Eusebius never tied Mark specifically with the Therapeutae or the scholasticism among them. If we can know anything about early Christian scholasticism in Alexandria, it is most likely Jewish, if not Philonic, in origin. ${ }^{70}$

If not institutionally, at least intellectually, Philo exerted his influence on the Alexandrian Christian community, beginning with Clement, and possibly with Pantaenus. This great cradle of Christian philosophy drew its inspiration from Alexandrian Judaism. Their Bible was an Alexandrian production, at least in their minds. Their tradition was littered with Jewish influences, with Aristobulus, the Wisdom of Solomon and Philo. Their understandings of philosophical and theological categories were, in many cases, articulated first by Philo himself. Eusebius could not have missed all of these influences. But things were more complicated with Philo, who lived at the time of the Apostles. His stamp was clearly visible in Alexandrian Christianity, as Eusebius knew, and he was a primary witness - the only surviving witness - to the earliest Egyptian Christianity as Eusebius wished to present it. So, when it suited his purposes, Philo was at once an honored Hebrew, a virtual convert to Christianity, and now an outsider providing "objective" eye-witness testimony to the community of the Therapeutae.

\section{Conclusion}

The great historian of early Christianity, Henry Chadwick, opened an essay on Philo with the ironic observation, "The history of Christian philosophy begins

\footnotetext{
${ }^{68}$ The literature on the Alexandrian Christian $\delta 1 \delta \alpha \sigma \kappa \alpha \lambda \varepsilon i ̃ o v$ is immense. Modern discussion must begin with the essays of Gustave Bardy, "Aux origenes de l'école d'Alexandrie," Revue des sciences religieuses 27 (1937): 65-90; and "Pour l'histoire de l'école d'Alexandrie," Vivre et Penser 2 (1942): 80-109. For Philo's potential role, see Annewies van den Hoek, "The Catechetical School of Early Christian Alexandria and Its Philonic Heritage," Harvard Theological Review 90 (1997): 59-87, and Gregory Sterling, "The School of Sacred Laws: The Social Setting of Philo's Treatises," Vigiliae Christianae 53 (1999): 148-64. For a convenient survey of the history of research on the school prior to Pantaenus, see Jakab, Ecclesia Alexandrina, 91-106.

${ }^{69}$ Hist. eccl. 5.10.1.

${ }^{70}$ See Van den Hoek, "The Catechetical School.” If Sterling is correct about Philo operating a school, then it is possible that Christians who borrowed Philo's exegetical method would also have borrowed the institutional model ("The School of Sacred Laws"). Sterling returns to the question in a forthcoming publication, "Philo's School: The Social Setting of Philo's Commentaries," in Sophisten in Hellenismus und Kaiserzeit: Orte, Methoden und Personen der Bildungsvermittlung, ed. Beatrice Wyss (Tübingen: Mohr Siebeck), in which he argues that Philo's commentaries are best viewed from an institutional scholastic setting. I would like to thank Prof. Sterling for sharing this essay with me.
} 
not with a Christian but with a Jew, Philo of Alexandria." ${ }^{71}$ Eusebius would likely have agreed, mutatis mutandis. It is remarkable that his biographies of Origen and Philo were so closely aligned. Philo in fact shared more in common with Origen than with any other figure presented in the Ecclesiastical History. But the religious status of Philo remained usefully ambiguous, at least in the Ecclesiastical History. He was not yet Philo Christianus, nor was he entirely still Philo Judaeus. For Eusebius, he was Philo Hebraicus, a designation that could be construed as it suited Eusebius' contextual needs. Philo was the sole witness to the earliest Alexandrian Christians, the Therapeutae, and he was a personal acquaintance of the Apostle Peter. So even though Eusebius did not quite "convert" Philo, he did respect Philo's role in the tradition of Alexandrian Christian exegesis. To do so was simply to follow his hero Origen, who repeatedly acknowledged Philo, usually anonymously, as a predecessor. For this reason, I think, Eusebius ironically portrayed Philo in terms similar to Origen as the model scholar, regardless of his ethnic or religious affiliation.

71 "Philo and the Beginnings of Christian Thought," in The Cambridge History of Later Greek and Early Medieval Philosophy, ed. A.A. Armstrong (Cambridge: Cambridge University Press, 1967), 137. 